The Jewish Legion and the First World War 
This page intentionally left blank 


\section{The Jewish Legion and the First World War}

Martin Watts 


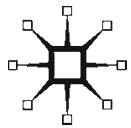

(c) Martin Watts 2004

Softcover reprint of the hardcover 1st edition 2004 978-1-4039-3921-0

All rights reserved. No reproduction, copy or transmission of this publication may be made without written permission.

No paragraph of this publication may be reproduced, copied or transmitted save with written permission or in accordance with the provisions of the Copyright, Designs and Patents Act 1988, or under the terms of any licence permitting limited copying issued by the Copyright Licensing Agency, 90 Tottenham Court Road, London W1T 4LP.

Any person who does any unauthorised act in relation to this publication may be liable to criminal prosecution and civil claims for damages.

The author has asserted his right to be identified as the author of this work in accordance with the Copyright, Designs and

Patents Act 1988.

First published 2004 by

PALGRAVE MACMILLAN

Houndmills, Basingstoke, Hampshire RG21 6XS and

175 Fifth Avenue, New York, N. Y. 10010

Companies and representatives throughout the world

PALGRAVE MACMILLAN is the global academic imprint of the Palgrave Macmillan division of St. Martin's Press, LLC and of Palgrave Macmillan Ltd. Macmillan ${ }^{\circledR}$ is a registered trademark in the United States, United Kingdom and other countries. Palgrave is a registered trademark in the European Union and other countries.

ISBN 978-1-349-51966-8 ISBN 978-0-230-51454-6 (eBook) DOI $10.1057 / 9780230514546$

This book is printed on paper suitable for recycling and made from fully managed and sustained forest sources.

A catalogue record for this book is available from the British Library.

Library of Congress Cataloging-in-Publication Data

Watts, Martin, 1953-

The Jewish Legion and the First World War / by Martin Watts.

p. $\mathrm{cm}$.

Includes bibliographical references and index.

1. Jewish Legion. 2. Great Britain. Army-History-World War, 1914-1918. 3. World War, 1914-1918-Regimental histories-Great Britain. 4. Zionism-History-20th century. 5. Great Britain-Ethnic relations-History-20th century. I. Title.

D568.7.W28 2004

940.4'1241'089924-dc22

2004049120

$\begin{array}{llllllllll}10 & 9 & 8 & 7 & 6 & 5 & 4 & 3 & 2 & 1\end{array}$

$\begin{array}{llllllllll}13 & 12 & 11 & 10 & 09 & 08 & 07 & 06 & 05 & 04\end{array}$ 
This book is dedicated to the memory of David Englander, Reader in History, the Open University

'Shalom, haver' 
This page intentionally left blank 


\section{Contents}

List of Illustrations viii

List of Maps $\quad$ ix

List of Tables $\quad \mathrm{x}$

Acknowledgements $\quad$ xi

List of Abbreviations xiii

Brief Biographies xiv

1 Introduction: a Matter of Record 1

2 The Zion Mule Corps 20

3 The Founding of the Legion: Part One 48

4 The Founding of the Legion: Part Two 76

5 Raising the Battalions: Great Britain 117

6 Raising the Battalions: the United States 138

7 Preparation and Prejudice 160

8 The Legion at War 182

9 Disturbance and Decline $\quad 201$

10 Conclusions: Legacy of the Legion 239

Appendix I: Strength Returns March 1918-May 1921

Appendix II: Maps 248

$\begin{array}{lr}\text { Notes } & 250\end{array}$

$\begin{array}{ll}\text { Bibliography } & 270\end{array}$

$\begin{array}{ll}\text { Index } & 279\end{array}$ 


\section{Illustrations}

1.1 ZOA citation, Capt. Philip Jacobs, 1968 (courtesy of $\mathrm{Mr}$ and Mrs Herbert Goldsmith, London, UK)

7.1 Recruits for the 40th (Palestine) Battalion, Royal Fusiliers, summer 1918 (by permission of the Imperial War Museum. IWM, No. Q12670)

7.2 Major James (de) Rothschild at Jaffa with recruits for the 40th (Palestine) Battalion, summer 1918 (by permission of the Imperial War Museum. IWM, No. Q12680)

7.3 Recruits for 40th (Palestine) Battalion, Jerusalem, summer 1918 (by permission of the Imperial War Museum. IWM, No. Q12671)

7.4 Recruits for the 40th (Palestine) Battalion, en route from Jaffa to Helmieh (Egypt), summer 1918 (by permission of the Imperial War Museum. IWM, No. Q12679)

7.5 Letter to Harry Levine from Levi Eshkol, 1964 (courtesy of Mrs Helen Finkel, New Jersey, USA)

8.1 Platoon of ' $A$ ' Company 38th at Giza, 1918. Pte. Berger is fourth from right, front row (courtesy of L. Berger, Edinburgh, UK)

9.1 Private Aaron Gitelson, 1919 (courtesy of Mr and Mrs Ash, New York, USA)

9.2 Private Aaron Gitelson and comrades, 1919 (courtesy of Mr and Mrs Ash, New York, USA)

10.1 Letter to Harry Levine from D. Ben-Gurion, 1964 (courtesy of Mrs Helen Finkel, New Jersey, USA) 


\section{Maps}

A.II.1 The landings at Gallipoli (courtesy of the Imperial War Museum)

A.II.2 Megiddo 1918 (courtesy of the Imperial War Museum) 


\section{Tables}

9.1 Disposition October $1918 \quad 205$

9.2 Courts martial summary August 1919

A.I.1 Strength returns March 1918-May 1921 


\section{Acknowledgements}

This work would not have been possible without the assistance, co-operation and patience of the curators, librarians and staff of the following institutions (located in London, unless otherwise stated):

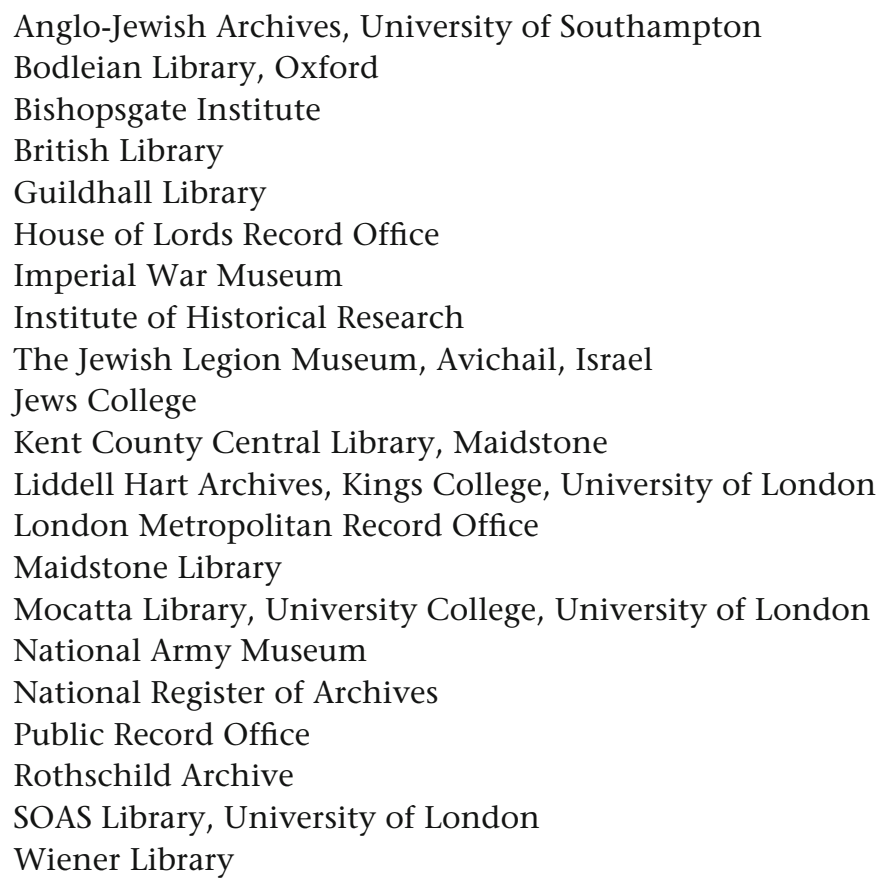

Particular acknowledgment is reserved for Lt.-Col. Pettifar (retd.), Major Bowes-Crick and Jim Kelleher at the Regimental Headquarters of the Royal Regiment of Fusiliers, HM Tower of London. They were introduced to me by Fred Baker (ex-RSM), my colleague and friend, to whom I owe a great deal.

I also wish to pay a personal tribute to those who have made it possible, through their friendship and support, for this work to be completed over the past eight years. They include the late Dr David Englander (an inspiration), the late Dr John Herman, Pat Upward, Tony Sawyer, Ralph Coney, Liz Fox and Robin Leach. I am indebted to 
Dr Bernard Waites for his friendly encouragement, patience and wise advice. Thanks, too, to Julian Putkowski, Dr Gerard Oram and Dr Buck Ryan.

Indebtedness and gratitude are also due to the correspondents and interviewees listed in the Bibliography. The photographs supplied by the Ash family of New York, the Finkel family of New Jersey, the Berger family of Edinburgh and the Goldsmith family of London are particularly appreciated. Warm thanks also to the Gildesgame Foundation and Laurence Hoppen, who succeeded in finding the resting place of the Legionnaire grandfather he never knew.

Finally, I wish to thank my wife Denise, daughters Helen and Laura, my Mum Vera and brother Nigel without whose love and unstinting faith I would have given up long ago. My only regret and sadness is that my Dad, Ron, did not live to see the completion of this research; I like to think there is a part of him in it. 


\section{Abbreviations}

$\begin{array}{ll}\text { AAG } & \text { Assistant Adjutant-General } \\ \text { AJA } & \text { Anglo-Jewish Archives } \\ \text { BAPIP } & \text { British Association of Palestine Israel Philatelists } \\ \text { BDBJ } & \text { Board of Deputies of British Jews } \\ \text { Bod. Lib. } & \text { Bodleian Library } \\ \text { CAB } & \text { Cabinet papers } \\ \text { CUP } & \text { Cambridge University Press } \\ \text { CZA } & \text { Central Zionist Archive, Jerusalem } \\ \text { EEF } & \text { Egyptian Expeditionary Force } \\ \text { FJPC } & \text { Foreign Jews Protection Committee } \\ \text { FO } & \text { Foreign Office papers } \\ \text { GHQ } & \text { General Head Quarters } \\ \text { GLRO } & \text { Greater London Record Office } \\ \text { GOC-in-C } & \text { General Officer Commanding-in-Chief } \\ \text { GS } & \text { General Staff } \\ \text { HO } & \text { Home Office papers } \\ \text { IWM } & \text { Imperial War Museum } \\ \text { JC } & \text { Jewish Chronicle } \\ \text { LHA } & \text { Liddell Hart Archives } \\ \text { MEF } & \text { Mediterranean Expeditionary Force } \\ \text { NCO } & \text { Non-Commissioned Officer } \\ \text { OUP } & \text { Oxford University Press } \\ \text { PRO } & \text { Public Record Office } \\ \text { QMG } & \text { Quartermaster-General } \\ \text { USSD } & \text { United States State Department } \\ \text { WO } & \text { War Office papers } \\ \text { ZMC } & \text { Zion Mule Corps } \\ \text { ZOA } & \text { Zionist Organisation of America } \\ \end{array}$




\section{Brief Biographies}

Allenby, Edmund Henry Hynman, Viscount (1861-1936)

A career soldier and cavalryman in the British Army, Edmund Allenby commanded the 1st Cavalry Division in 1914, and was promoted to command the Third Army on the western front in 1915. In 1917 he was sent to Egypt as commander-in-chief, where he earned his reputation during two campaigns that resulted in taking Jerusalem and then defeating the Turks at Megiddo and Damascus. Allenby commanded a multi-national army and managed to gain the respect not only of his troops but also of Arab and Jewish leaders. After a short spell as military governor and leave at home, Allenby was made high commissioner to Egypt in 1919 until his retirement in 1925.

\section{Amery, Leopold Charles Maurice Stennett (1873-1955)}

Leopold Amery was a Conservative MP from 1911 to 1945, who served as an assistant-secretary to the War Cabinet of Lloyd George. An advocate of the British Empire and Commonwealth, Amery was a pro-Zionist who considered that British support for an independent Jewish state in Palestine would be of benefit to Britain's imperial and strategic interests. He was responsible for the first draft of the Balfour Declaration and campaigned for the establishment of the Jewish Legion on behalf of Jabotinsky. Later colonial secretary, Amery's final ministerial post was as secretary of state for Burma and India during Winston Churchill's premiership 1940-1945.

\section{Ben-Gurion, David (1886-1973)}

Born David Green in Poland, Ben-Gurion emigrated to Palestine in 1906 and, working on the land, joined Poale Zion, the Zionist Socialist group. Before the First World War he went with Isaac Ben-Zvi to university in Constantinople to study law but returned to Palestine on the entry of Turkey into the conflict. Expelled by the Turks, Ben-Gurion and Ben-Zvi (collectively known as the 'Benim') went to the USA where they assisted in the foundation and recruitment of the American contingent of the Jewish Legion. Ben-Gurion served as a corporal in the Legion despite upsetting his superiors by delivering political speeches to his comrades. As a labour leader after the war, involved with the Histradut (Jewish Workers Federation) and the Haganah (Jewish self-defence group), BenGurion's influence grew until, in 1948, he announced the founding of 
the state of Israel. He was prime minister between 1948 and 1953, and again between 1955 and 1963 when he was succeeded by another former Legionnaire, Levi Eshkol.

\section{Jabotinsky, Vladimir (1880-1940)}

Vladimir Jabotinsky's background was distinctly middle class and he received a Russian education in his hometown of Odessa, before moving on to study law in Italy and Rome. He became an international correspondent for home newspapers and had a gift for languages; skills that made him a powerful propagandist and speaker. His interest in Zionism began with the Russian pogroms of 1903, and he became a regular attendee at Zionist Congresses and meetings. Jabotinsky's commitment to the founding of an independent Jewish state was absolute and, in the First World War, he poured his energy into founding the Jewish Legion. His views were not shared by other Zionist leaders, including his personal friend Chaim Weizmann, but he did succeed with the Jewish Legion project and was commissioned into the 38th Battalion and saw active service at the battle of Megiddo in September 1918. After the war Jabotinsky had a brief period as political officer to the Zionist commission, but quit after becoming disillusioned with what he saw as the British authorities' failure to implement the promises of the Balfour Declaration. As a leader of the Haganah (selfdefence) he took part in the Arab-Jewish riots in 1920, was arrested and subsequently released. Afterwards, he served with the Zionist Executive and went on to become the founder of the Zionist youth movement Betar (Brit Trumpeldor) and led the revisionist movement in opposition to the socialist Zionist groups that existed throughout the mandate period. In 1940, after being banned from Palestine by the mandatory authority, Jabotinsky succumbed to a heart attack whilst visiting the Betar movement in New York.

\section{Patterson, John Henry (1867-1947)}

Originally a civil engineer from a middle-class Anglo-Irish protestant family, Patterson made his name during the second Boer war as volunteer in the Imperial Yeomanry. He was promoted from lieutenant to lieutenant-colonel in less than six months and earned a DSO and several mentions. During this campaign he gained the acquaintance of the future Lord Allenby and remained listed in the territorial force until he resigned in 1913 over Irish home rule. In the meantime he worked in East Africa building bridges and becoming a famous big game hunter; his clients included the former president of the United States, Theodore Roosevelt. He was able to resume his military career in 
1915 and commanded the Zion Mule Corps and, subsequently, the 38th Battalion Royal Fusiliers - the first unit of what was to become known as the Jewish Legion. He left the Legion at the end of 1919 and remained a friend of Jabotinsky throughout the inter-war period.

\section{Rothschild, Lionel Walter, 2nd Lord (1868-1937)}

Succeeding to the title in 1915, Lord Rothschild took over as the widely recognised leader of the Jewish community in Britain, at a time when questions raised by the war and its influence on the future had a profound effect upon Anglo-Jewish relations. Although originally opposed to the Jewish Legion idea, Rothschild adapted to the inevitable and attempted to provide a bridge between the opposing factions. The combination of compulsion, and the transfer of some Jewish soldiers from other regiments, persuaded Rothschild to support the Jewish battalions. He was also extremely influential in ensuring that the battalions would not bear a Jewish name until distinction in the field had been achieved. It should also be noted that Rothschild had to deal with the welfare issues arising out of the Military Service Convention, and that it was to him that the note containing the Balfour Declaration was addressed.

\section{Sokolow, Nahum (1859-1936)}

A historian and journalist from eastern Poland, Sokolow was an able linguist and scholar who became general secretary of the Zionist Organisation from 1906 to 1909. A colleague and supporter of his friend Chaim Weizmann, he worked for the Zionist cause in Britain during the First World War, preparing diplomatic support for the Balfour Declaration and placing pressure on the British government over the Jewish Legion question. He played a leading part at the peace conference and then became chairman of the Zionist executive and was later president during Weizmann's 'interregnum' following the publication of the Passfield report in 1931.

\section{Swaythling, Edwin Samuel, 2nd Baron (Lord Montagu) (1879-1924)}

Second son of the 1st Baron, Edwin Montagu was a Liberal MP prior to taking his seat in the House of Lords, serving as secretary of state for India from 1917 to 1922. Before this appointment he was financial secretary and the minister for munitions. Lord Swaythling was a leading antiZionist Jew who regarded himself as an Englishman first and foremost, and did not recognise the Jewish people as comprising a separate state. He led the delegations to the War Office that nearly succeeded in having the Jewish battalions scrapped before they were formed, and was also instrumental in softening the original drafts of the Balfour Declaration. 


\section{Sykes, Sir Mark (1879-1919)}

A Conservative MP, Mark Sykes' diplomatic skills were used to provide the British government with advice on Middle-Eastern matters during the First World War. He was responsible for negotiating a secret agreement with the French foreign minister, François Georges Picot, in 1916 (the Sykes-Picot agreement), that set out post-war Anglo-French spheres of control and influence in the Middle East. After this work had been completed, Sykes became interested and supportive of Zionism and the Jewish Legion, and contributed to the drafts that went on to become the Balfour Declaration. He believed that Arabs and Jews would be able to happily co-exist and was therefore disappointed to discover, on a visit to Palestine prior to his early death, the extent of Arab resentment to the implications of the declaration.

\section{Trumpeldor, Joseph (1880-1920)}

Joseph Trumpeldor is believed to be the first Jew to receive a commission in the Tsarist army following his bravery at the defence of Port Arthur in 1904 during the Russo-Japanese war. Although severely wounded, losing his left arm, he survived and was sent to Japan as a prisoner of war. Whilst in the camp he conducted classes in Zionism and established a Jewish prisoners organisation accompanied by a newsletter. After his repatriation he emigrated to Palestine in 1912 and met Jabotinsky in Alexandria in 1915. Together they played the leading roles in organising the Zion Mule Corps and, when Jabotinsky left following a disagreement over the military employment of the corps, Trumpeldor served as second-in-command to Patterson before taking over for the final stages of the Gallipoli campaign. He then came to Britain and assisted Jabotinsky in his fight to raise the Jewish battalions, but left when it became apparent that he would not be offered a commission in the new unit. Trumpeldor then accepted an offer by the Provisional Government in Russia to raise a Jewish army for deployment against the Turks in the Caucasus, but this came to naught with the overthrow of Kerensky. Returning to Palestine in 1919, Trumpeldor took an active part in Jewish self-defence of the settlements, and became a hero when killed by Arabs during the massacre at Tel Hai on 1 March 1920. Jabotinsky founded the nationalist youth movement Brit Trumpeldor (Betar) in his name.

\section{Weizmann, Chaim (1874-1952)}

Born and raised in the Pale of Settlement, Chaim Weizmann initially pursued an academic career as a chemist, which led him to work at Manchester University from 1904. By then he had also become leader of 
a Zionist opposition group from where he first attempted to combine the theoretical and practical elements of Zionism he had encountered at congress and during his visits to Zionists across Russia. Introduced, early in the First World War, to members of the British establishment such as David Lloyd George and C.P. Scott, Weizmann again combined his activities as a research scientist and Zionist leader with remarkable effect. He solved the acetone supply problem for the munitions minister (then Winston Churchill) and, despite his opposition to the official Zionist policy of neutrality, nurtured his political relationships to the extent that he advised on the wording of the Balfour Declaration and suggested that it be addressed to Lord Rothschild. In obtaining the support of the British government in this matter his influence was seen to have outweighed that of the traditional Anglo-Jewish establishment as represented by Lucien Wolf. In addition, despite his disapproval of Jabotinsky's methods, Weizmann befriended and supported him in his endeavours to raise a Jewish Legion, something he himself tried to do early in the Second World War. Chaim Weizmann was at the forefront of Zionist politics throughout the inter-war period and his pragmatism and diplomacy were characterised by moderation and realism. Whilst this caused him to lose the leadership of the Zionist Congress for four years in the early 1930s, and again in late 1946, his outstanding work on behalf of the Jewish people was recognised when he was invited to become the first president of Israel, a post he held from 1948 until his death in 1952.

\section{Wolf, Lucien (1857-1930)}

By profession a historian and journalist, being the founder and president of the Jewish Historical Society of England and the editor of the Jewish World, Lucien Wolf also acted as secretary of the Conjoint Committee Foreign Branch. This influential committee, often consulted by the government, included representatives of the Board of Deputies of British Jews and the Anglo-Jewish Association. As a leading anti-Zionist he was central to the Jewish opposition to the Jewish Legion idea and the Balfour Declaration. Although defeated on both issues, it remains the case that both fell short of the expectations of their advocates and this was due in no small part to the work of Wolf, who went on to assist in the drafting of the Minorities Treaties at the peace conference of 1919 . 